\title{
Rethinking cluster evolution: Actors, institutional configurations, and new path development
}

Progress in Human Geography

(C) The Author(s) 2020

Article reuse guidelines: sagepub.com/journals-permissions DOI: 10.1 I77/0309/32520926587 journals.sagepub.com/home/phg

\section{Jack Laurie Harris (1)}

National University of Singapore, Singapore

\begin{abstract}
Despite a flourishing evolutionary economic geography, the cluster evolution literature has been somewhat left behind, and remains somewhat simplistic and deterministic. This article seeks to form a synthesis from recent conceptual advancements in the evolutionary and institutional economic geographies, in pursuit of expanding the cluster evolution literature. In the process it produces a novel way of exploring cluster evolution, through the concept of cluster institutional configurations, which focuses on the ability of different actors to navigate potential lock-ins and to drive cluster evolution, and connects it to broader debates in economic geography.
\end{abstract}

\section{Keywords}

cluster evolution, cluster life-cycle, institution, institutional configurations, new path development, path creation, path dependence

\section{Introduction}

Despite the popularity of the cluster concept in economic geography, our evolutionary understanding of it is underwhelming. Despite accumulating a plethora of research over the last 30 years (see, for example, Amin and Thrift, 1992; Asheim, 2000; Markusen, 1996; Scott, 1988, 1998), the approach to conceptualising their evolution has largely been to simplify it with inappropriate biological metaphors and to neglect the role of agency in causal explanation. While the cluster evolution literature has been slow to explore new avenues of research (see, for an exception, Martin and Sunley, 2011), the broader evolutionary economic geography (EEG) literature which has grown rapidly in recent years has not, and lessons can be learned from it.
The importation of new concepts from outside of geography has generated significant debate amongst evolutionary economic geographers (see, for example, Martin and Sunley, 2015). However, the use of these concepts has seldom transferred to cluster evolution and has not energised that debate. Similarly, EEG has only provided partial and fragmented insights to clusters, instead focusing on industrial change occurring predominantly at the regional level (MacKinnon et al., 2019). Analysing industrial change at the regional scale

\section{Corresponding author:}

Jack Laurie Harris, National University of Singapore, I Arts Link, Singapore, I19260; Geography and Environmental Science, University of Southampton, UK.

Emails: jack.harris@u.nus.edu; j.l.harris@soton.ac.uk 
misses important spatial factors and variations. Clusters, industries, and regions are directly implicated through co-evolutionary dynamics (Gong and Hassink, 2019); indeed, following Martin and Sunley (2015), all can be seen as overlapping and interconnected complex systems. While the focus of a regional complex system and its industrial path is activities occurring within the territorially defined area, a cluster complex system is concerned with the production of externalities through clustering of related firms and the reflexive effects of these externalities on said firms (Martin and Sunley, 2015). Such a complex systems approach takes a relational view of clusters and sees them as dynamic entities capable of existing within and across broader regional boundaries, rather than singular and fixed at territorial scales (Martin and Sunley, 2011). Thus, clusters may be more Porterian in nature, consisting of geographic concentrations of interconnected companies across interrelated industries (Porter, 1998); or, they may be more specialised, singleindustry concentrations benefitting from Marshall-Arrow-Romer (Arrow, 1962; Marshall, 1890; Romer, 1986) externalities; but the focus remains on the way in which the system of interrelated firms produces and benefits from externalities. By exploring the evolution of clusters, it provides a more nuanced understanding of the role of space and externalities within the region, and potentially the inter-path relations of clusters, regions and even broader industries (Hassink et al., 2019). Greater confluence of these literatures, then, particularly around recently popularised notions of new path development, may revitalise the cluster evolution literature first and foremost, and add further rigour to the EEG literature.

I understand cluster evolution as being about how two aspects of the cluster evolve. Firstly, it is about the changing populations and characteristics of the actors involved, such as the various types of firms, support or government organisations, either found within or who influence the cluster through various relationships and shared goals. Secondly, it is about the changing externalities that can be found and accessed by these actors. The cluster evolution literature emerged as a response to static cluster research and, over time, a corpus of work has congregated around the cluster life-cycle approach (Menzel and Fornahl, 2010). This approach offers a useful heuristic for tracing the evolution of a cluster and has identified a number of ways in which cluster evolution can be driven, namely via links to industry life-cycles, frameworks of rules and policies, or through firm and network dynamics. However, the cluster life-cycle approach has gone through a period of stagnation itself and could benefit from a conversation with recent conceptual advances from evolutionary and institutional economic geographies.

Both the cluster evolution and the broader EEG literatures have, in recent years, faced calls for more actor-centric approaches (Hassink et al., 2019; Trippl et al., 2015). Additionally, economic geographers have argued for better understanding of institutions within the two literatures (Hassink et al., 2014; MacKinnon et al., 2009; Trippl et al., 2015). There have been a number of important institutional contributions in recent years (for example: Gertler, 2010; Maskell and Malmberg, 2007; Zukauskaite et al., 2017), but most significantly, I draw on Bathelt and Glückler's (2014) reconceptualisation of institutions in economic geography, developing it for cluster evolution to introduce the novel concept of cluster institutional configurations, defined here as the combination of shared goals, behaviours, and relations between cluster actors involved in a cluster. I argue that by tracing the evolution of such cluster institutional configurations, we can gain a better understanding of how actors drive clusters throughout their evolutionary trajectories.

The aim of this contribution, then, is to produce a synthesis between the cluster evolution 


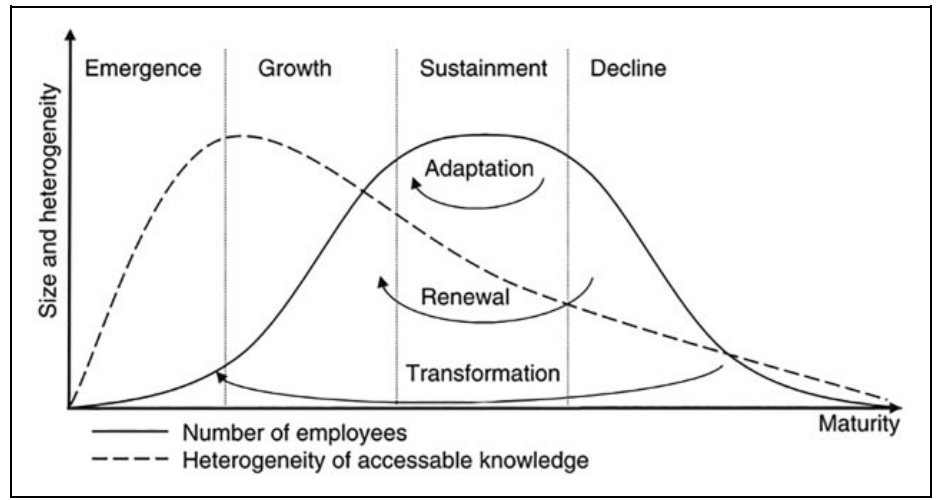

Figure I. The cluster life-cycle model. Source: Menzel and Fornahl (2010: 2II).

literature and recent advances in evolutionary and institutional economic geographies, advancing research into cluster evolution. The paper will start by outlining the literature on the cluster life-cycle approach, highlighting the key findings and limitations, before Sections III and IV identify the most promising theoretical advancements from both evolutionary and institutional economic geographies, respectively. For the former, the new path development literature offers much conceptual utility that could be applied to clusters and their life-cycle stages. For the latter, Bathelt and Glückler's (2014) work on institutions offers a relational perspective to institutions that, when developed and applied to clusters, can offer a platform for understanding actors as drivers of cluster evolution in a path dependent manner. Following this, in Section V, I will explore how cluster institutional configurations shape cluster evolutionary trajectories. Drawing on examples, I suggest how key actors navigate the preconditions available to them, utilising them to initiate new path developments that precipitate cluster emergence and create institutional configurations in the process. These cluster institutional configurations then act as the preconditions for future rounds of path development that condition and constrain the ability of actors to prevent negative lock-ins and ensure ongoing cluster evolution through path development. The paper finishes with some concluding directions for future research.

\section{The cluster life-cycle approach}

Conceptualisations of cluster evolution revolve around the idea of a life-cycle. The cluster life-cycle model has gone through multiple iterations and is best explained in Menzel and Fornahl's (2010) important contribution. The cluster life-cycle model (Figure 1) tracks the evolution of a cluster through four stages, from emergence, through growth and maturation (sustainment), to decline. The general idea is that all clusters will eventually go through the same immutable process starting with emergence and culminating with decline. This is because the model is highly path dependent and it is thought that the benefits which enabled cluster emergence and growth will eventually stifle continued growth and generate negative lock-in, causing decline and the eventual death of the cluster (Menzel and Fornahl, 2010). However, the model has developed over time to include the processes of adaptation, renewal and transformation, providing clusters with more possibilities in their evolutionary trajectories.

Clusters are considered beneficial because they provide externalities to firms. However, as Menzel and Fornahl (2010) point out, a 'cluster paradox' exists which is the conflict between 
Table I. Summary of cluster evolution drivers.

\begin{tabular}{|c|c|c|c|}
\hline $\begin{array}{l}\text { Driver of } \\
\text { cluster } \\
\text { evolution }\end{array}$ & Examples & Limitations & Key contributions \\
\hline Industry & $\begin{array}{l}\text { - Industry and technology life- } \\
\text { cycles }\end{array}$ & $\begin{array}{l}\text { - Conflicting empirical evidence } \\
\text { - Little appreciation of internal } \\
\text { cluster processes }\end{array}$ & $\begin{array}{l}\text { - Audretsch and } \\
\text { Feldman (1996) } \\
\text { - Klepper (2007) }\end{array}$ \\
\hline Institutions & $\begin{array}{l}\text { - Multi-scalar frameworks of } \\
\text { formal rules and policies } \\
\text { being (un)favourable }\end{array}$ & $\begin{array}{l}\text { - Limited acknowledgement of } \\
\text { different evolution of clusters } \\
\text { within same frameworks } \\
\text { - Actors not well developed }\end{array}$ & $\begin{array}{l}\text { - Maskell and Mámberg } \\
\text { (2007) }\end{array}$ \\
\hline $\begin{array}{l}\text { Firms and } \\
\text { networks }\end{array}$ & $\begin{array}{l}\text { - Firm heterogeneity } \\
\text { - Network heterogeneity } \\
\text { - Local and extra-local } \\
\text { networks } \\
\text { - Firm capabilities and } \\
\text { strategies }\end{array}$ & $\begin{array}{l}\text { - No appreciation of the role of } \\
\text { state or institutions } \\
\text { - Little understanding of how } \\
\text { agency affects networks } \\
\text { - Is not applicable to all firms, } \\
\text { clusters, or stages of evolution }\end{array}$ & $\begin{array}{l}\text { - Li et al. }(2012) \\
\text { - Potter and Watts } \\
\text { (20I4) } \\
\text { - Bathelt et al. (2004) } \\
\text { - Ter Wal and Boschma } \\
\text { (20II) }\end{array}$ \\
\hline Actor & $\begin{array}{l}\text { - Collective action } \\
\text { - Entrepreneurs finding new } \\
\text { technologies or business } \\
\text { opportunities } \\
\text { - Government actors } \\
\text { becoming policy } \\
\text { entrepreneurs }\end{array}$ & $\begin{array}{l}\text { - Little focus on the relationship } \\
\text { between different types of } \\
\text { actors } \\
\text { - Weak appreciation of agency }\end{array}$ & $\begin{array}{l}\text { - Miörner and Trippl } \\
\text { (20I7) } \\
\text { - Sydow et al. (20I0) } \\
\text { - Tomlinson and } \\
\text { Branston (20|4) }\end{array}$ \\
\hline
\end{tabular}

Source: Author's own.

how a cluster can become specialised enough that it provides beneficial externalities to firms in certain industries without becoming so specialised that knowledge and networks become homogeneous and inhibit innovation. This means that clusters, by their very nature, are constantly at risk of negative lock-in and decline. However, this approach has generated a large empirical body of literature that suggests ways in which negative lock-in can be escaped (Table 1). We know that clusters can perform differently, despite being in the same industry, same national context, or same stage of the cluster life-cycle. Furthermore, we know that the conditions that made clusters successful during one stage of the cluster life-cycle do not necessarily generate the same or indeed any success during other stages of the cluster life-cycle. The literature has produced reasons to account for this but none offer a complete picture without limitations (Table 1). For example, we know that during certain stages of an industry lifecycle clusters are considered to be more or less beneficial for firms (Crespo, 2011); that certain institutional frameworks are more conducive to cluster growth or decline (Maskell and Malmberg, 2007); and that firms themselves can influence cluster evolution by their individual strategies and capabilities, or through their population dynamics, such as firm spinoffs or deaths (Hervas-Oliver and Albors-Garrigos, 2014).

The literature thus far, then, has identified multiple drivers of cluster evolution, but they are typically quite deterministic. Positive changes in industries, technologies, firm dynamics, and frameworks of rules and policies will lead to ongoing cluster growth while negative changes will prompt negative growth. While undoubtedly accurate in many instances, 
the lack of insight surrounding actors and how they can (un)intentionally mediate cluster evolution has stunted growth in the literature and meant that cluster-based policies have often worked poorly (Lovering, 1999; Trippl et al., 2015).

Recently, the role of agency in cluster evolution has become a focus of the literature. Several approaches have sought to look at how collective action can halt the decline of clusters and precipitate renewal. It has been highlighted that firms in clusters can collectively lobby for policy changes that impact the behaviours of cluster actors in beneficial ways (Tomlinson and Branston, 2014) or source new resources for cluster actors to utilise (Miörner and Trippl, 2017). Others have demonstrated that it requires focused and coordinated action not only to initiate action, but also to deliberately re-coordinate the cluster networks afterwards so that the change becomes path dependent (Sydow et al., 2010). Such are the importance of collaborative approaches, it has been found that the stage of cluster evolution influences the potential for renewal because of the capability for collective action; mature clusters are more likely to fare better than emerging clusters during periods of crisis because they are more capable of using established networks to generate collaborative strategies and competences that are mutually beneficial to cluster growth (Skålholt and Thune, 2014).

Another argument for collective action is that firm-led technological change alone is often not enough for cluster evolution (Coenen et al., 2015). Rather, it needs to be co-evolutionary with institutional and industrial change. Merely introducing technologies, particularly into old industrial regions, does not alone instigate the change necessary, as technological experimentation needs policy change to facilitate its adoption and spread. This has led others to focus on the role of actors in changing policies. Martin and Martin (2017) argued that the policy capacities of regions, in how policy makers identify and enact opportunities, are vital for path development and to prevent lock-ins. Similarly, Smith et al. (2017) explored how a new cluster emerged out of the remnants of a declining one due to the actions of a 'policy entrepreneur', which was needed to navigate the policy changes necessary for this to occur.

This small but promising literature that focuses more closely on actors in cluster evolution has demonstrated that further research is needed in this nascent area. Given the recognition in the literature that conditions that were once highly beneficial to a particular stage of the cluster life-cycle may not be suitable for others, this actor-centric literature is promising as it has demonstrated how actors can mediate the evolutionary trajectories of clusters, prevent negative lock-in, and upgrade the cluster. One limitation is that the literature has not typically engaged with the more recent concepts that have emerged out of the EEG literature more broadly. To this end, the following section seeks to provide a summary of the recent debate on path creation and new path development.

\section{Evolutionary economic geography and new path development}

The need for a more actor-centric approach to understanding cluster evolution is timely as EEG has recently seen ongoing and energetic debates about the role of actors in path creation and new path development (Hassink et al, 2019; MacKinnon et al., 2019). Path creation and new path development, defined as "the emergence and growth of new industries and economic activities in regions' (MacKinnon et al., 2019: 114), are largely synonymous terms that aim to understand how actors, utilising pre-existing conditions, can create new pathways or later changes to the pathway through their actions. The rising popularity of these literatures can be traced to the limitations of the lock-in focus of the path dependence literature. In Martin's 
(2010: 22) Roepke lecture, he argued that the existing appreciation of path dependence spoke 'to the reproduction of what exists, to yet more of the same, but not to evolution'. He suggested that actors may play a greater role in the creation of new paths than has previously been stated, and that while, over time, some paths will become locked-in to a 'stable state', other paths will face continuous change and evolution in response to changing economic conditions. This prompted economic geographers to explore ideas of path creation to identify ways that actors create new industrial pathways. More recently, the new path development moniker has been introduced to encapsulate a broader typology of ways in which actors can create new paths and make changes to existing paths (Hassink et al., 2019). Because of this broader typology, I make use of the new path development term in this paper.

Given the potential for negative lock-in, the cluster evolution literature needs an understanding of how actors can mediate these evolutionary trajectories through path development. The literature on new path development aims to tackle such issues by exploring how actors create and develop industrial pathways. In this regard, it offers potential for a better understanding of cluster evolution trajectories because it has, as the following section demonstrates, been successful in understanding the emergence of new technologies and industries, developed conceptual rigour on the role of actors in this process, and begun to focus on what happens to a pathway after the initial moment of path creation and the role of actors in the ongoing path development.

Simmie (2012) was one of the first to take the idea of path creation further, developing a hybrid socio-economic theory of path creation and applying it to the creation of new paths through technological innovation. Comparing the niche US and Danish wind power industry, and drawing heavily on sociological work on path creation (Garud and Karnøe, 2001; Garud et al., 2010), he argued for an actor-oriented theory where knowledgeable agents play a vital role in recognising the initial existing conditions, initiating a moment of path creation, and then continually overcoming any barriers to the implementation of these technologies. While Simmie's (2012) focus on technological change emphasised innovators and inventors, other applications have explored a wider range of actors. Dawley et al. (2015), drawing on previous work in the area (Dawley, 2014), trace the role of policy actors in path creation for the offshore wind industries in the north-east of England and Scotland. They find that the heightened powers given to Scotland because of the devolved UK state meant that they had more ability to set ambitious targets, garner strong political support for the sector and greater capacity to attract investment from both international firms and the UK government. More recently, MacKinnon et al. (2019) have sought to link the path creation literature with other literatures in economic geography, namely GPN2.0, to provide a more comprehensive understanding of how new pathways occur within regions due to certain actors.

The role of actors and their agency during the moment of path creation has attracted a deeper conceptual focus within EEG. For example, Steen (2016) engaged the broader social sciences to argue for an enhanced understanding of temporality in path creation. The basis for these claims is that entrepreneurship and technological innovation are inherently futureoriented, and that behaviour considers not just the past and present but also the future circumstances and consequences (Emirbayer and Mische, 1998; Martin and Sunley, 2010). For Steen (2016: 1610), then, 'agency is thus intertemporal: ongoing processes of becoming connect the past - which constitutes the basis for ongoing action - with the future in the form of visions or expectations of how action may unfold'. This means that the origin of moments of path creation and development, as well as 
Table 2. Typology of new path development.

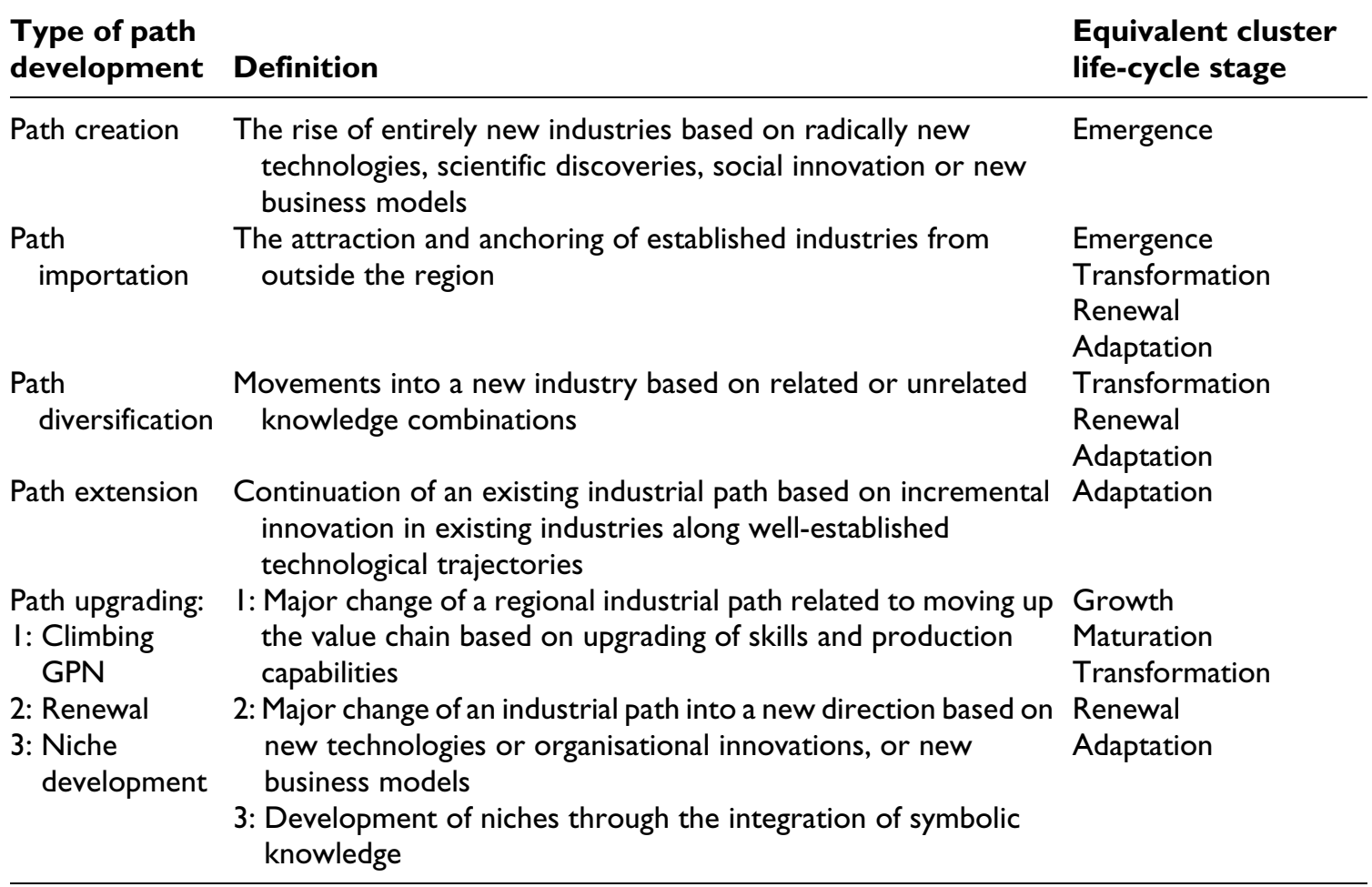

Compiled using: Grillitsch et al. (20।8); Hassink et al. (20।9); Isaksen et al. (20।8); Martin and Sunley (2006); Tödtling and Trippl (20I3).

their success, depend on the ability of actors to derive compelling 'narratives' that compete for attention, often in light of certain 'anti-narratives' (Garud et al., 2010), to legitimise changes.

Building on this work, economic geographers have shifted their focus beyond the initial moment of path creation to try to capture an understanding of the broader types of path development that can occur. As Table 2 demonstrates, this work has produced an array of types of path development that could be applied to more cluster life-cycle stages than the path creation work, which was largely focused on the initial process of emergence. While the new path development literature still highlights the importance of path creation, it also emphasises other types of actor-led path development that can occur throughout the evolution of a pathway as the same conceptual understandings of how actors utilise existing preconditions to create new industrial pathways can be applied to these latter stages of path development.

New path development provides us with multiple ways of understanding how cluster emergence could come to fruition, a better appreciation of what cluster growth or maturation constitutes through processes of path upgrading, and multiple ways of exploring how clusters can adapt, renew, or transform. Some types of path development could mean different things for the various stages of cluster evolution. Path diversification, for instance, could mean that an already mature cluster incorporates new (un)related industries to adapt to changes, or that an already declining cluster 
Progress in Human Geography $X X(X)$

transforms into a new (un)related industry to arrest the decline. By applying this typology of path development to clusters, we can hopefully develop a better understanding of how actors can change the evolutionary trajectories of clusters over long periods of time in a path dependent manner.

Evidently, the new path development literature has developed a strong conceptual foundation for a variety of types of new path development that have close parallels with, and can be applied to, cluster evolution. They have also engaged broadly with other literatures to understand how actors can enact these path developments through exploring aspects such as agency, temporality and narratives. This goes beyond what is currently present in the cluster evolution literature and offers significant potential for its development. I argue here that applying this approach to the variety of possible cluster evolutionary trajectories can provide an interesting way to explore not just the notable moments of path development that generate cluster emergence or cluster transformation to another industry, but also how potential lock-ins are navigated, by actors, throughout an evolutionary pathway that does not have such industry changes, during the classic cluster life-cycle progression from emergence, through growth to maturation.

The challenge of understanding actors' role in this is made harder by clusters being highly heterogeneous, constituted by many different actors. Each of these actors is going to have different goals and needs, capabilities to identify potential lock-ins, and capacities to enact change. Therefore, to better understand how actors can drive cluster evolutionary trajectories requires us to go outside of EEG to institutional economic geography. The following section will explore a recent conceptual advance in institutional economic geography that promises to add value to such an approach.

\section{Introducing cluster institutional configurations}

The cluster evolution and the broader EEG literatures have long faced calls for better integration with institutions, particularly for their focus on the firm as an economistic unit (Hassink et al., 2014, 2019; MacKinnon et al., 2009; Pike et al., 2016; Trippl et al., 2015). Institutional approaches can be found in both the cluster evolution and broader EEG literatures, but they typically fall foul of the same problems that have beleaguered the cluster evolution literature, notably an inability to adequately explain how actors drive cluster evolution. At the same time, institutional economic geographers have also highlighted the need for a better understanding of the role of actors and geography within institutional approaches (Gertler, 2010; Zukauskaite et al., 2017). This section aims to explain how the concept of cluster institutional configurations can remedy some of these issues. To do so I first explore some existing institutional contributions to the literature, before introducing Bathelt and Glückler's (2014) relational approach to institutions and applying it to cluster evolution through the novel concept of cluster institutional configurations.

Institutional approaches to cluster evolution have usually sought to understand how clusters are conditioned and constrained by formal institutional frameworks at the various territorial scales they are located within (Maskell and Malmberg, 2007). These frameworks consist of the rules, laws and regulations at multiple geographical scales, from the local, through the regional and national, to the supra-national. One problematic tendency with this is the suggestion that a cluster's performance is predetermined by its (mis)fortune to be located either within or outside of an institutional framework that was conducive to the emergence and growth of cluster externalities. Cluster evolution in this perspective is seen through the lock-in lens of path dependence, whereby clusters emerge due 
to a set of pre-existing conditions, in this case an enabling institutional framework, and will survive within this institutional framework until external factors deem it no longer suitable, at which point it will decline regardless of the agency of actors within it.

The new path development literature has attempted to resolve such a structural approach to give actors more agency, drawing on institutional thought in the process (Grillitsch and Sotarauta, 2019). Particularly, they have used the concept of institutional entrepreneurship to explore how actors are capable of breaking free from existing multi-scalar institutional frameworks to create new paths (MacKinnon et al., 2019). This balance between structure and agency is evidently a step in the right direction and should be applied to understand how actors can create and drive cluster evolutionary trajectories. However, while the current use of institutional entrepreneurship is fine for exploring individual moments of new path development and the role of actors within them, a better approach is required for understanding the long-term path development of a cluster evolutionary trajectory. To do so, I introduce the concept of cluster institutional configurations, defined as the combination of shared goals, behaviours, and relations between cluster actors involved in a cluster. The cluster institutional configuration responsible for the new path development that precipitated cluster emergence is going to, in turn, condition and constrain future path development, shaping what is possible for future path development. Thus, tracing the ongoing evolution of the key actors, their relationships and behaviours, will provide an understanding of how actors can continue to drive the evolutionary trajectories of clusters.

To develop the concept of cluster institutional configurations, I draw upon Bathelt and Glückler's (2014: 346) relationally constituted approach towards defining institutions as 'forms of ongoing and relatively stable patterns of social practice based on mutual expectations that owe their existence to either purposeful constitution or unintentional emergence'. Their relational approach makes it ideal for understanding the evolving roles and relationships between key actors. Additionally, institutions have long been criticised for being a muddied concept that has meant different things at different times (Gertler, 2010). Bathelt and Glückler's (2014) conceptualisation of institutions sees them in a much more minimal light, which helps to provide a distinction between actors, institutions and the role of existing institutional environments. With this in mind, and in order to reduce confusion on institutions satisfactorily, it is also important to clearly define what institutions are not. Firstly, the simple behavioural regularities of individual actors are not institutions because they are not shared amongst other actors, nor do they influence other actors' behaviours. Only if these simple regularities generate expectations, create patterns of interaction, or are supported by effective sanctions do they become institutions (Bathelt and Glückler, 2012). This means that firm routines are not necessarily institutions, as they are often suggested to be in EEG (MacKinnon et al., 2009).

Secondly, organisations are often referred to as institutions when they are actually sets of actors with targeted goals. In pursuing these goals, the sets of actors may have institutions amongst them, such as shared work codes and ethics, but their mere existence is not tantamount to an institution. Finally, rules, laws, or regulations are also not necessarily institutions, only becoming so if behaviour is influenced by them. At their inception they are merely codified prescriptions that aim to condition and constrain behaviour, but, as with any law in society, they are not necessarily obeyed in the intended manner or indeed at all. Rather, institutions develop in response to these rules, either as intended or unintended behaviours, through the social interactions of actors. 
Institutions are, then, responses to formal rules and informal conventions, that manifest as shared and socially accepted patterns of behaviour, and which are constituted through the active relations between actors as they pursue their socio-economic goals (Bathelt and Glückler, 2014). In this sense, institutions are not a priori spatial constructions, but are instead generated by actors in response to their socioeconomic challenges. Cluster actors and their institutions are conditioned and constrained by the 'institutional thickness' of the region they are territorially embedded within (Zukauskaite et al., 2017), but do not necessarily embrace those formal rules and informal conventions. This means that institutions in clusters do not necessarily mirror the frameworks of rules that they are territorially embedded within; rather, cluster actors are going to shape the institutions that form through their goals and actions, in the process forming a cluster institutional configuration that will affect the availability of externalities and provide (dis)advantages to local firms. This is not simply a case of identifying actors present within clusters but instead understanding their goals, ability to pursue them, and how they enact their agency in pursuit of them. How actors decide upon their goals, mobilise them into shared goals, and then execute their realisation is as important to understand in cluster evolution as looking at the externalities that are the resulting remnants of such action. However, this understanding is complicated by clusters being highly heterogeneous in their actor make-up across (sub)national boundaries and industries.

The term organisational 'thickness' has been used by economic geographers to describe how different regions have varying populations of firms, government actors, and extra-firm actors (Zukauskaite et al., 2017). These actors can be distinguished further in terms of their size, capabilities, or performance, and regions have been categorised as organisationally 'thick' or 'thin', amongst others (Isaksen and Trippl, 2016;
Trippl et al., 2018), in response. This varying organisational 'thickness' is an important precondition for any type of path development occurring. Indeed, as Grillitsch and Sotarauta (2019) argue, not all actors have the same ability to enact transformative changes in regional development, and so the actors (and their capabilities) present will affect not just the potential for change but the type of change that occurs. They identify innovative entrepreneurship, institutional entrepreneurship, and place-based leadership as possible types of change, arguing that variations in their use leads to uneven regional path development. For example, innovative entrepreneurship alone is rarely enough for significant changes in path development and relies upon some institutional entrepreneurship to provide the favourable shared goals and relations to take advantage of the innovation.

Consequently, I use the concept of cluster institutional configurations here as the combination of shared goals, behaviours, and relations between (firm and government) actors involved in a cluster. In reality, a cluster could consist of any number of types or groups of actors. For simplification, I settle here for the use of firm actors because they are the inevitable backbone of any cluster, while government actors have a long history of cluster policies, both successfully and unsuccessfully (Lovering, 1999). Thus, clusters are likely to consist of changing populations of firm and government actors, manifest in different institutional configurations, which are going to have different effects on their evolutionary trajectories (Figure 2).

Table 3 provides examples of how cluster institutional configurations may influence cluster evolutionary trajectories. The shared goals formed by actors will determine the potential outcomes in the cluster in terms of the institutions and externalities that are created, which in turn will drive the clusters' evolutionary trajectories. The potential outcomes are heavily dependent on the actors and their capabilities who share the goal. For example, the more 


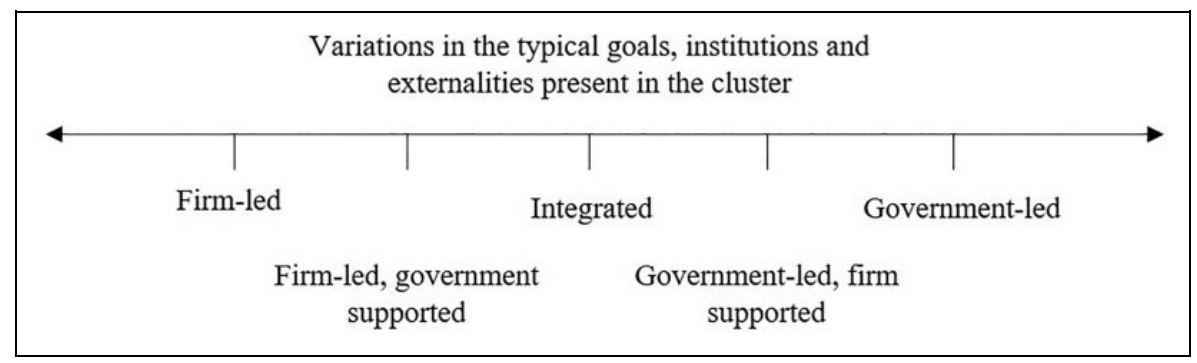

Figure 2. Variations in cluster institutional configurations. Source: author's own.

Table 3. Potential impacts of institutional configurations on cluster evolution.

\begin{tabular}{|c|c|c|}
\hline $\begin{array}{l}\text { Potential shared goals of an insti- } \\
\text { tutional configuration }\end{array}$ & Potential outcomes in the cluster & $\begin{array}{l}\text { Possible stage of } \\
\text { cluster development }\end{array}$ \\
\hline $\begin{array}{l}\text { Create new co-locations of firms and } \\
\text { externalities } \\
\text { (path creation or importation) }\end{array}$ & $\begin{array}{l}\text { Create a shared hub or organisations to } \\
\text { facilitate networking } \\
\text { Create a set of formal rules and policies } \\
\text { to encourage activity }\end{array}$ & Emergence \\
\hline $\begin{array}{l}\text { Diversify the cluster with other } \\
\text { industries } \\
\text { (path diversification) }\end{array}$ & $\begin{array}{l}\text { Launch firm spinoffs } \\
\text { Build relationships with other industries }\end{array}$ & $\begin{array}{l}\text { Transformation } \\
\text { Renewal } \\
\text { Adaptation }\end{array}$ \\
\hline $\begin{array}{l}\text { Make the cluster internationally } \\
\text { competitive } \\
\text { (path upgrading } \\
\text { Climbing GPN) }\end{array}$ & $\begin{array}{l}\text { Seek relations with extra-local actors and } \\
\text { research organisations } \\
\text { Seek extra funding for R\&D }\end{array}$ & $\begin{array}{l}\text { Emergence } \\
\text { Growth } \\
\text { Maturation }\end{array}$ \\
\hline $\begin{array}{l}\text { Revive a declining cluster } \\
\text { (path upgrading, } \\
\text { renewal) }\end{array}$ & $\begin{array}{l}\text { Rework relations between existing } \\
\text { strong actors } \\
\text { Adopt new shared practices, products, } \\
\text { etc. }\end{array}$ & $\begin{array}{l}\text { Transformation } \\
\text { Renewal }\end{array}$ \\
\hline $\begin{array}{l}\text { Specialise the cluster around existing } \\
\text { industry } \\
\text { (path upgrading, } \\
\text { niche development) }\end{array}$ & $\begin{array}{l}\text { Strengthen relations between existing } \\
\text { strong actors } \\
\text { Develop industry specific resources }\end{array}$ & $\begin{array}{l}\text { Emergence } \\
\text { Growth } \\
\text { Maturation }\end{array}$ \\
\hline
\end{tabular}

Source: Author's own.

government actors involved in the initial moment of path creation, the likelier we are to see new rules, regulations and policies emerge that affect cluster activities. Alternatively, the type of inter-firm relations that emerge will depend on the capabilities of the firms present in the cluster. For example, larger firms with higher absorptive capacity may benefit more from extra-local relations with large firms outside of the cluster, leading to path upgrading via climbing GPNs. Conversely, small start-ups may develop the type of knowledge spillovers that lend to niche development.

Thus, as the next section will explicate through multiple examples, the cluster institutional configuration of shared goals, behaviours, and relations between actors present in a cluster is going to play an important role in the 
ability of actors to change the evolutionary trajectory of the cluster through navigating potential lock-ins and initiating moments of path development.

\section{Towards institutional configurations as drivers of cluster evolution}

Thus far, I have identified recent conceptual advances from both the evolutionary and institutional economic geographies that can contribute to a new approach to cluster evolution. To this end, I introduced the novel concept of cluster institutional configurations, which shall be explored further in this section as a way of understanding how actors drive cluster evolution. I will first explore how variations in the actors present in institutional configurations may generate cluster emergence in different ways. Following that, I will use empirical examples to demonstrate multiple ways that institutional configurations constrain future rounds of path development and how actors can navigate this, before ending with an example of an institutional configuration initiating multiple rounds of path development successively.

In a new path development perspective to cluster emergence, clusters do not emerge due to random chance or serendipity, but due to the agency of key actors. While the existing approaches to cluster emergence identified in Section II and other literatures on regional development are correct to suggest that the institutional frameworks or the organisational 'thickness' that a cluster is territorially embedded within are going to impact cluster emergence (Cooke, 2001; Isaksen and Trippl, 2016; Trippl et al., 2018), in this approach they are merely the preconditions that actors can utilise to trigger cluster emergence (Isaksen, 2016). This means that actors are not allpowerful and are heavily influenced by the various types of regions they find themselves in, but that new path development is ultimately prefaced on actors precipitating such change. In addition, there are many types of actor change, both transformative and reproductive (Coe and Jordhus-Lier, 2011), and not all will create the moment of new path development necessary for cluster emergence to occur. For example, as Grillitsch and Sotarauta (2019) write, Schumpeterian innovative entrepreneurship is rarely enough to trigger new development paths in and of itself; rather, institutional entrepreneurship must occur alongside it to produce a conducive institutional environment for such innovation to occur.

Thus, for any meaningful new path development to occur it will require the networks and shared behaviours to support it of a cluster institutional configuration; regardless of the organisational thickness present in the broader region, actors whose goals and capabilities are sufficient to support such networks and shared behaviours are needed. For example, Isaksen (2016) details that the emergence of the Arendal boatbuilding cluster relied on key entrepreneurs constructing funding networks to support their innovation; the emergence of firm spin-offs using an innovation alone was not enough but instead required a firm-led institutional configuration which had the shared goal of supporting a cluster of boat builders with funding networks.

While the Arendal cluster is an example of a firm-led institutional configuration generating cluster emergence, the Research Triangle Park and Silicon Valley clusters demonstrate the success that can occur when government and other supporting actors are involved in the institutional configuration. With firm and government actors sharing the goal of supporting new cluster growth in these locations, policy makers were quickly able to hear the needs of firms and provide the funding necessary to support them and facilitate cluster emergence through policy changes (Mazzucato, 2013). Without government involvement these entrepreneurs would likely not have had access to such beneficial funding policies and cluster emergence may not 
have occurred. As such, it demonstrates the potential of an integrated, firm and government, institutional configuration in driving cluster evolution due to the potential for change that this actor mix offers.

While the previous two examples of cluster emergence suggest that path creation is likelier to emerge due to firm-led institutional configurations that can be amplified through government involvement, cluster emergence due to path importation is seemingly more likely to occur because of government-led institutional configurations. The technopoles that emerged during the 1980s and 1990s were predominantly state-planned initiatives that occurred throughout the world after the success of Research Triangle Park and Silicon Valley (Mazzucato, 2013). Governments began attempting the 'Siliconization' of their own economies by importing ideas and technologies in places like Zhongguancun Technopole near Beijing and Sophia Antipolis Technology Park in France (Roper and Grimes, 2005); they recognised the benefits of such technology clusters but needed to import ideas, firms and technologies to realise them because the local preconditions were unsuitable. While the government-led institutional configurations provided the policies, funding, and facilities necessary for the potential clusters to thrive, firms struggled to replicate the strong trust-based networks and knowledge spillovers which worked so well in Silicon Valley (Castells and Hall, 1994), and which would have enabled them to properly utilise the funding and facilities provided by the government actors, leading to Cooke's (2001: 950) description as 'cathedrals in the desert, often in agglomeration but not clustering'. This shows that a government-led institutional configuration with government actors simply creating new policies or rules does not necessarily correlate with realised changes in the institutions at the cluster level, because firms must embrace these changes and form shared behaviours in response. It contrasts to the emergence of Research Triangle Park and Silicon Valley, where the government launched policies that they knew the existing entrepreneurs demanded because of the firm-led, government-supported institutional configuration, which meant the policies formed beneficial institutions in the clusters as entrepreneurs responded as intended. This echoes how firm spin-offs alone are often not enough for cluster emergence as they do not generate the shared behaviours, relations and goals necessary to support them.

From this it can be suggested that the preexisting organisational 'thickness' and institutional frameworks are important in conditioning and constraining the process by which cluster emergence occurs; however, actors ultimately must utilise these preconditions to trigger cluster emergence. Furthermore, the type of new path development that occurs during cluster emergence is driven by the type of key actors that come to the fore, due to their different goals and capacity for institutional change. While path creation is likelier to occur because of firms and entrepreneurs seeking support for their innovations, path importation may be a tool of government actors to achieve results.

The cluster institutional configurations that develop during cluster emergence will have path dependent effects on the evolutionary trajectories of the cluster. Just as the pre-existing organisational 'thickness' and institutional frameworks are preconditions, so too now is the cluster institutional configuration a precondition for ongoing path development. The relations between key actors in the institutional configuration and the institutions they have created condition and constrain any opportunities for actors to generate new forms of path development by shaping actors' capacity to identify potential lock-ins or opportunities, and their ability to enact the path development necessary. It is for this reason that moments of path development that alter the evolutionary trajectories of clusters cannot be seen in isolation but must be seen through a path dependent lens whereby the 
cluster institutional configuration conditions and constrains what is possible.

The declining Cognac cluster in France offers an example of how the existing cluster institutional configuration is a constraining force. Firms identified that the cluster was in an increasingly negative lock-in and decline but failed multiple times to create the institutional change necessary to arrest the decline because the existing institutions were so strongly supported. This is unsurprising as previously the institutional configuration acted as an example of positive lock-in, whereby the shared behaviour of only producing Cognac had meant highly beneficial protection by the EUs authenticity regulations as a premium brand. Eventually, as conditions worsened, firms managed to convince others to dispense with the institution of only producing Cognac, and to start producing other spirits during the off-season to not waste excess capacity, a path diversification which spurred cluster adaptation (Moodysson and Sack, 2016). This demonstrates that even when actors are aware of negative lock-in, the cluster institutional configuration present will act as a constraining force on what is possible, meaning that not all attempts by actors to initiate path developments will be successful if they cannot build the narratives necessary to convince other actors.

Path development may also take a long time to occur if actors do not immediately recognise the changes necessary. For example, the Staffordshire ceramics cluster had been in a long period of gradual decline over multiple decades before key firms realised that increased networking and idea exchange, as well as better collective action to ensure the achievement of shared goals such as better vocational training, brand identity, and funding, could produce the path renewal necessary for cluster renewal (Tomlinson and Branston, 2014). While cluster institutional configurations are a constraining force on the ability of actors to initiate path development, actors themselves must have the ability to identify what is needed and to construct the narratives necessary to generate the change; without these key actors and narratives the negative lock-in and cluster decline will continue unabated.

Cluster institutional configurations are also dynamic and malleable. As contested path developments occur, not all actors are necessarily included. For example, some firms in the Tuttlingen medical instruments cluster recognised that the existing institutional configuration that had enabled cluster emergence could not deal with the threat of international competition (Staber and Sautter, 2011). They responded by forming new relationships with firms outside the cluster, setting new cluster standards in the process, to create global value chains to compete on a cost basis and utilising path upgrading to continue cluster growth. However, firms that refused to heed the threat and participate in global value chains either failed and disappeared or were absorbed by the successful firms. This shows that while institutional configurations account for the shared goals and behaviours of actors in the cluster, each actor will also have their own individual goals and routines which may see them perform differently to other actors in the cluster.

These examples demonstrate that actors will often need to change the institutions within an institutional configuration to enact the necessary path development. Alternatively, it is possible to change the broader actor structure of an institutional configuration to precipitate path development. Smith et al.'s (2017) study of the Nottingham pharmaceutical cluster show it is sometimes necessary to incorporate new actors to resolve negative lock-ins. Plans to regenerate the declining cluster repeatedly failed as the existing institutional configuration of local firms and universities could not agree on changes. Competing universities and firms each had their own goals and were unwilling to sacrifice to create unified shared goals. It was not until the government regional development 
agency stepped in to mediate as a 'policy entrepreneur' and successfully united the firms and universities behind a common goal that a biotechnology incubator was created which enabled firms and universities to mutually benefit from monetised research. This facilitated path diversification into the broader biosciences industry and cluster renewal.

Finally, I offer an example of how a cluster institutional configuration could successfully drive a cluster from emergence, through growth, to maturation, using successive moments of path development. In Martin and Martin's (2017) study on the Scania new media cluster, they found that in 2002 a group of entrepreneurs and regional policy makers combined to create a cluster called M-Town to facilitate connections between the ICT and new media industries. Strong networking externalities facilitated cluster emergence through this path creation. In 2004, these actors then applied for funding at the national scale, taking advantage of existing policies to provide the funding necessary to ensure cluster growth. This path extension served to navigate any potential lock-ins that may have occurred as the firms grew larger and needed more capital, enabling them to grow unabated. By 2009, however, the national funding had finished. Faced with the potential negative consequences of a lack of capital at a time when firms had grown larger and more plentiful, the institutional configuration of key firms and regional government actors actively sought to generate new funding by attracting EU structural grants, to ensure that the strong growth they were experiencing did not dwindle. They did so by attracting larger private sector firms to the project to convince the funding commission that the cluster was ready to grow to a maturation stage through the path extension facilitated by this funding. The funding was then used for projects to garner future collaboration between the firms present and to attract new firm entrants. This case study shows how a cluster institutional configuration may need to path develop multiple times to prevent potential negative lock-in and to get the cluster from emergence to maturation, using both institutional change in the existing institutional configuration and changes to the actor structure. Furthermore, it demonstrates the benefit of not seeing policies in broader institutional frameworks as institutions automatically; both the national and EU funding policies existed but did not become institutions for the cluster actors until they were applied for and adopted by the institutional configuration.

Throughout a cluster's evolution, then, there may be many times that actors need to initiate path development to navigate negative lock-in and ensure the ongoing survival of the cluster. I have provided examples to illustrate how existing cluster institutional configurations could inhibit the ability to path develop, continuing the decline of the cluster, but also how actors are capable of enacting the path development necessary through either institutional change or changing the actor structure of the institutional configuration. I have shown that while cluster institutional configurations are a constraining force and path dependent, they are dynamic and malleable and can be navigated by actors. Importantly, I have demonstrated why a path dependent institutional approach is needed to understand cluster evolution, as while institutional frameworks condition and constrain cluster emergence, changing institutional configurations continually constrain the ongoing evolutionary trajectories of clusters. By tracing the evolution of such cluster institutional configurations, we can gain a better understanding of how actors drive cluster evolution.

\section{Conclusion}

This paper has made the case for a new approach to investigating cluster evolution that prioritises understanding the role of actors in a path dependent way, by combining recent 
conceptual advances from institutional and evolutionary economic geographies with the existing appreciation of cluster life-cycles. I have argued that the novel concept of cluster institutional configurations provides a way of exploring how cluster evolution is driven, or not, by the key actors present in a cluster and highlighted some of the issues facing them. It places the focus of study on the actors themselves and their rationales for action as driven by the socio-economic context they are present within, moving away from frameworks as the driving factors themselves but instead as being contextual preconditions that are manipulated by actors to achieve their goals (Bathelt and Glückler, 2014).

Looking ahead, this framework offers a way to understand cluster evolutionary trajectories past the initial moment of emergence. While the initial moment of new path development that generates cluster emergence out of preconditions is vital to understand, there is a longer and more iterative process of evolution that must also be understood, and the institutional configuration present during these decisive moments will shape ongoing evolution. I have shown institutional configurations to be constraining forces but also dynamic and malleable, provided actors can construct the narratives necessary to enact change. Additionally, I identify some mechanisms by which actors can drive cluster evolution, namely changing the existing shared goals and behaviours of cluster actors, or changing the actor structure of the institutional configuration. To maximise its utility, comparative research programmes would be ideal to explore as great a variety of actors as possible, particularly across national lines, as it provides ample opportunity to explore how different national contexts and policy frameworks are utilised by myriad actors. Furthermore, doing long-run evolutionary research that goes past the emergence of new clusters would be beneficial to improve our path development conceptualisation. One last caveat is that I have only highlighted some limited examples of where actors have tried and failed to generate path development. It is vital going forwards to not just look at the successful attempts at path development but also the ones that had no effect, and most certainly the ones that had detrimental effects. The lessons learned from these failures are just as important as the successes.

\section{Acknowledgements}

I would like to thank Henry Yeung, Neil Coe, Karen Lai, Godfrey Yeung, Stuart Dawley and Peter Sunley for their critical and insightful comments at various stages, as well as Christian Berndt and the four anonymous reviewers for their constructive comments.

\section{Declaration of conflicting interests}

The author(s) declared no potential conflicts of interest with respect to the research, authorship, and/or publication of this article.

\section{Funding}

The authors disclosed receipt of the following financial support for the research, authorship, and/or publication of this article: National University of Singapore.

\section{ORCID iD}

Jack Laurie Harris (D) https://orcid.org/0000-00028441-1661

\section{References}

Amin A and Thrift N (1992) Neo-Marshallian nodes in global networks. International Journal of Urban and Regional Research 16: 571-587.

Arrow L (1962) The economic implications of learning by doing. The Review of Economic Studies 29: 155-173.

Asheim B (2000) Industrial districts: The contributions of Marshall and beyond. In: Clark GL, Feldman M and Gertler M (eds) The Oxford Handbook of Economic Geography. Oxford: Oxford University Press, 413-431.

Audretsch D and Feldman MP (1996) Innovative clusters and the industry life cycle. Review of Industrial Organization 11(2): 253-273.

Bathelt H and Glückler J (2012) Wirtschaftsgeographie: Okonomische Beziehungen in Raumlicher Perspektive 
[Economic Geography: Economic Relations in Spatial Perspective]. Stuttgart: Ulmer, UTB.

Bathelt H and Glückler J (2014) Institutional change in economic geography. Progress in Human Geography 38(3): 340-363.

Bathelt H, Malmberg A and Maskell P (2004) Clusters and knowledge: Local buzz, global pipelines and the process of knowledge creation. Progress in Human Geography 28: 31-56.

Castells M and Hall P (1994) Technopoles of the World: The Making of 21st Century Industrial Complexes. London: Routledge.

Coe NM and Jordhus-Lier DC (2011) Constrained agency? Re-evaluating the geographies of labour. Progress in Human Geography 35: 211-233.

Coenen L, Moodysson J and Martin H (2015) Path renewal in old industrial regions: Possibilities and limitations for regional innovation policy. Regional Studies 49(5): $850-865$.

Cooke P (2001) Regional innovation systems, clusters, and the knowledge economy. Industrial and Corporate Change 10(4): 945-974.

Crespo J (2011) How emergence conditions of technological clusters affect their viability: Theoretical perspectives on cluster life cycles. European Planning Studies 19(12): 2025-2046.

Dawley S (2014) Creating new paths? Offshore wind, policy activism, and peripheral region development. Economic Geography 90(1): 91-112.

Dawley S, MacKinnon D, Cumbers A and Pike A (2015) Policy activism and regional path creation: The promotion of offshore wind in North East England and Scotland. Cambridge Journal of Regions, Economy and Society 8: 257-272.

Emirbayer M and Mische A (1998) What is agency? American Journal of Sociology 103(4): 962-1023.

Garud R and Karnøe P (2001) Path Dependence and Creation. London: Lawrence Erlbaum Associates.

Garud R, Kumaraswamy A and Karnøe P (2010) Path dependency or path creation? Journal of Management Studies 47(4): 760-774.

Gertler M (2010) Rules of the game: The place of institutions in regional economic change. Regional Studies 44(1): 1-15.

Gong H and Hassink R (2019) Co-evolution in contemporary economic geography: Towards a theoretical framework. Regional Studies 53(9): 1344-1355.
Grillitsch M and Sotarauta M (2019) Trinity of change agency, regional development paths and opportunity spaces. Progress in Human Geography. Epub ahead of print 13 June 2019. DOI: 10.1177/030913251 9853870.

Grillitsch M, Asheim B and Trippl M (2018) Unrelated knowledge combinations: The unexplored potential for regional industrial path development. Cambridge Journal of Regions, Economy and Society 11: 257-274.

Hassink R, Klaerding C and Marques P (2014) Advancing evolutionary economic geography by engaged pluralism. Regional Studies 48(7): 1295-1307.

Hassink R, Isaksen A and Trippl M (2019) Towards a comprehensive understanding of new regional industrial path development. Regional Studies 53(11): 1636-1645.

Hervas-Oliver J and Albors-Garrigos J (2014) Are technology gatekeepers renewing clusters? Understanding gatekeepers and their dynamics across cluster life cycles. Entrepreneurship and Regional Development 26(5-6): 431-452.

Isaksen A (2016) Cluster emergence: Combining preexisting conditions and triggering factors. Entrepreneurship and Regional Development 28(9-10): 704-723.

Isaksen A and Trippl M (2016) Regional industrial path development in different types of regions: A conceptual analysis. In: Parrilli D, Fitjar R and Rodriguez-Pose A (eds) Innovation Drivers and Regional Innovation Strategy. London: Routledge, 66-84.

Isaksen A, Tödtling F and Trippl M (2018) Innovation policies for regional structural change: Combining actor-based and system-based strategies. In: Isaksen A, Martin R and Trippl M (eds) New Avenues for Regional Innovation Systems - Theoretical Advances, Empirical Cases and Policy Lessons. Cham: Springer, 221-238.

Klepper S (2007) Disagreements, spinoffs, and the evolution of Detroit as the capital of the US automobile industry. Management Science 54(4): 616-631.

Li PF, Bathelt H and Wang J (2012) Network dynamics and cluster evolution. Changing trajectories of the aluminium industry in Dali, China. Journal of Economic Geography 12(1): 127-155.

Lovering J (1999) Theory led by policy? The inadequacies of the 'new regionalism. International Journal of Urban and Economic Research 23: 379-395. 
MacKinnon D, Cumbers A and Pike A (2009) Evolution in economic geography: Institutions, political economy, and adaptation. Economic Geography 85(2): 129-150.

MacKinnon D, Dawley S, Pike A and Cumbers A (2019) Rethinking path creation: A geographical political economy approach. Economic Geography 95(2): 113-135.

Markusen A (1996) Sticky places in slippery space: A typology of industrial districts. Economic Geography 72(3): 293-313.

Marshall A (1890) Principles of Economics. London: Macmillan.

Martin R (2010) Roepke Lecture in Economic Geography: Rethinking regional path dependence: Beyond lock-in to evolution. Economic Geography 86(1): 1-27.

Martin H and Martin R (2017) Policy capacities for new regional industrial path development: The case of new media and biogas in southern Sweden. Environment and Planning C: Politics and Space 35(3): $518-536$.

Martin R and Sunley P (2010) The place of path dependence in an evolutionary perspective on the economic landscape. In: Boschma R and Martin R (eds) The Handbook of Evolutionary Economic Geography. Cheltenham: Edward Elgar, 62-92.

Martin R and Sunley P (2011) Conceptualizing cluster evolution: Beyond the life cycle model? Regional Studies 45(10): 1299-1318.

Martin R and Sunley P (2015) Towards a developmental turn in evolutionary economic geography? Regional Studies 49(5): 712-732.

Maskell P and Malmberg A (2007) Myopia, knowledge development and cluster evolution. Journal of Economic Geography 7: 603-618.

Mazzucato M (2013) The Entrepreneurial State. Debunking Public vs. Private Sector Myths. London: Anthem Press.

Menzel M and Fornahl D (2010) Cluster life cycles dimensions and rationales of cluster evolution. Industrial and Corporate Change 19: 205-238.

Miörner J and Trippl M (2017) Paving the way for new regional industrial paths: Actors and modes of change in Scania's games industry. European Planning Studies 25(3): 481-497.

Moodysson J and Sack L (2016) Institutional stability and industry renewal: Diverging trajectories in the Cognac beverage cluster. Industry and Innovation 23(5): 448-464.
Pike A, MacKinnon D, Cumbers A, Dawley S and McMaster R (2016) Doing evolution in economic geography. Economic Geography 92(2): 123-144.

Porter M (1998) On Competition. Cambridge, MA: Harvard Business School Press.

Potter A and Watts HD (2014) Revisiting Marshall's agglomeration economies: Technological relatedness and the evolution of the Sheffield metals cluster. Regional Studies 48(4): 603-623.

Romer PM (1986) Increasing returns and long-run growth. The Journal of Political Economy 94(October): 1002-1037.

Roper S and Grimes S (2005) Wireless valley, silicon wadi and digital island: Helsinki, Tel Aviv and Dublin and the ICT global production network. Geoforum 36: 297-313

Scott AJ (1988) Regions and the World Economy: The Coming Shape of Global Production, Competition, and Political Order. Oxford: Oxford University Press.

Scott AJ (1998) Regions and the World Economy. Oxford: Oxford University Press.

Simmie J (2012) Path dependence and new technological path creation in the Danish wind power industry. European Planning Studies 20(5): 753-772.

Skålholt A and Thune T (2014) Coping with economic crises: The role of clusters. European Planning Studies 22(10): 1993-2010.

Smith D, Rossiter W and McDonald-Junor D (2017) Adaptive capability and path creation in the post-industrial city: The case of Nottingham's biotechnology sector. Cambridge Journal of Regions, Economy and Society 10: 491-508.

Staber U and Sautter B (2011) Who are we, and do we need to change? Cluster identity and life cycle. Regional Studies 45(10): 1349-1361.

Steen M (2016) Reconsidering path creation in economic geography: Aspects of agency, temporality and methods. European Planning Studies 24(9): 1605-1622.

Sydow J, Lerch F and Staber U (2010) Planning for path dependence? The case of a network in the BerlinBrandenburg optics cluster. Economic Geography 86(2): 173-195.

Ter Wal ALJ and Boschma R (2011) Co-evolution of firms, industries and networks in space. Regional Studies 45(7): 919-933.

Tödtling F and Trippl M (2013) Transformation of regional innovation systems: From old legacies to new 
development paths. In: Cooke P (ed.) Re-framing Regional Development. London: Routledge, 297-317.

Tomlinson PR and Branston JR (2014) Turning the tide: Prospects for an industrial renaissance in the North Staffordshire ceramics industrial district. Cambridge Journal of Regions, Economy and Society 7: 489-507.

Trippl M, Grillitsch M and Isaksen A (2018) Exogenous sources of regional industrial change: Attraction and absorption of non-local knowledge for new path development. Progress in Human Geography 42(5): 687-705.

Trippl M, Grillitsch M, Isaksen A and Sinozic T (2015) Perspectives on cluster evolution: Critical review and future research issues. European Planning Studies 23(10): 2028-2044.

Zukauskaite E, Trippl M and Plechero M (2017) Institutional thickness revisited. Economic Geography 93(4): 325-345.

\section{Author biography}

Jack Laurie Harris is a Research fellow at the University of Southampton. His research explores the institutional and evolutionary economic geographies of the software and advanced manufacturing industries. 